\title{
Leaf-Cutting Ants Toxicity of Limonexic Acid and Degraded Limonoids from Raulinoa echinata. X-Ray Structure of Epoxy-fraxinellone
}

\author{
Maique W. Biavatti ${ }^{*, a}$, Rosângela Westerlon ${ }^{a}$, Paulo C. Vieira $^{b}$, M. Fátima G. F. da Silva ${ }^{b}$, \\ João B. Fernandes ${ }^{b}$, M. Fernanda G. V. Peñaflor ${ }^{c}$, Odair C. Bueno ${ }^{c}$ and Javier Ellena $^{d}$ \\ ${ }^{a}$ Universidade do Vale do Itajaí, Programa de Pós-Graduação em Ciências Farmacêuticas, CP 360, 88303-202 \\ Itajaí - SC, Brazil \\ ${ }^{b}$ Departamento de Química, Universidade Federal de São Carlos, CP 676, 13565-905 São Carlos - SP, Brazil \\ ${ }^{c}$ Centro de Estudos de Insetos Sociais, Universidade Estadual de São Paulo, Rio Claro - SP, Brazil \\ ${ }^{d}$ Instituto de Física de São Carlos, Universidade de São Paulo, São Carlos - SP, Brazil
}

\begin{abstract}
A investigação fitoquímica das raízes de Raulinoa echinata, planta endêmica do Vale do Itajaí/ SC, levou ao isolamento e identificação dos limonóides degradados: fraxinelona, fraxinelonona e epoxi-fraxinelona. O último foi anteriormente isolado dos caules, porém sua configuração relativa não foi resolvida por experimentos de RMN. Este trabalho apresenta a análise de difração de raios-X da epoxi-fraxinelona, descreve o isolamento da fraxinelonona e fraxinelona pela primeira vez em Raulinoa, e a atividade tóxica da primeira sobre formigas cortadeiras (Atta sexdens rubropilosa). Pouca atividade foi observada para o limonóide degradado testado; entretanto, o limonóide ácido limonéxico isolado dos caules, apresentou alta toxicidade contra as formigas cortadeiras, reduzindo consideravelmente a longevidade das mesmas, em comparação com o controle.

Phytochemical survey of roots extracts of the South Brazilian endemic plant Raulinoa echinata Cowan, Rutaceae led to the isolation of known degraded limonoids: fraxinellone, fraxinellonone and epoxy-fraxinellone. The latter was previously isolated also from the stems, but the relative configuration could not be solved by NMR experiments. This paper deals with the X-ray diffraction analysis of epoxy-fraxinellone and its toxicity to leaf-cutting ants, describes the isolation of fraxinellonone and fraxinellone for the first time in Raulinoa. Epoxy-fraxinellone showed no toxicity to the leaf-cutting ants (Atta sexdens rubropilosa). The limonoid limonexic acid, isolated from stems, presented high toxicity to the leaf-cutting ants, diminishing considerably their longevity.
\end{abstract}

Keywords: Raulinoa echinata, degraded limonoids, limonexic acid, Atta sexdens rubropilosa, $\mathrm{X}$-ray structure

\section{Introduction}

Raulinoa is a monospecific genus and the species Raulinoa echinata Cowan (Rutaceae) is endemic in the Itajaí Valley, SC, Brazil. ${ }^{1}$ This endangered perennial woody shrub is characterized by the presence of spines (popularly know as Cutia-de-espinho) and has only been found in a short interval $(1000 \mathrm{~m})$ on the frequently inundated banks of Itajaí river in an approximate altitude of $100 \mathrm{~m}$, showing a high degree of adaptation to the environment.

We have previously reported the isolation and biological activities of some compounds of $R$. echinata. ${ }^{2}$

* e-mail: maique@univali.br
In continuation of our search for compounds and natural products to be used in the control of leaf-cutting ants, we have investigated the hexane extracts of roots of $R$. echinata leading to the isolation of typical rutaceous degraded limonoids: fraxinellone (1), fraxinellonone (2) and new epoxy-fraxinellone (3). The extracts of the stems furnished the known limonin precursor, limonexic acid (4).

Leaf-cutting ants are one of the most serious agricultural pests in South American countries and the biological control of these insects has been the aim of many studies. Their control can be achieved by means of intoxicating the leaf-cutting ants $^{3}$ or inhibiting the growth of their symbiotic fungus.

In this paper we describe the isolation, structural determination and evaluation of the activity of degraded 
limonoids and limonoids as toxicants to the leaf-cutting ants Atta sexdens rubropilosa.<smiles>CC1=C2C(=O)O[C@@H](c3ccoc3)[C@@]2(C)CCC1</smiles>

(1)

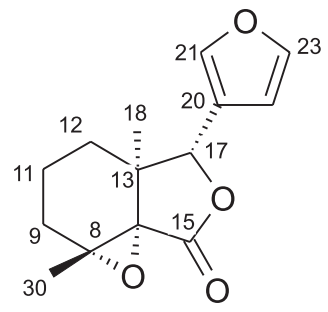

(3)

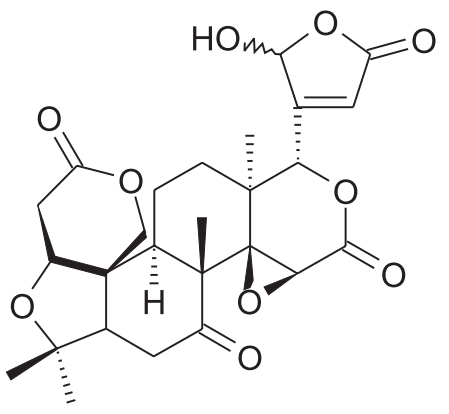

(4)

\section{Experimental}

\section{General experimental procedures}

NMR spectra: a Bruker DRX-400 spectrometer, operating at $400.13 \mathrm{MHz}$ for ${ }^{1} \mathrm{H}$ and $100.62 \mathrm{MHz}$ for ${ }^{13} \mathrm{C}$ was used.2 All spectra were run in $\mathrm{CDCl}_{3}$ using TMS as internal standard.

\section{Single crystal X-ray analysis}

Low temperature X-ray diffraction data collection was performed at 120(2) K, on an Enraf-Nonius Kappa-CCD diffractometer equipped with an Oxford Cryosystem liquid $\mathrm{N}_{2}$ device, using graphite-monochromated MoK $\alpha$ radiation $\left(0.71073 \AA\right.$ ). Data were collected up to $52.7^{\circ}$ in $2 \theta$, with a redundancy of 4 . The final unit cell parameters were based on all reflections. Data collections were made using the COLLECT program; ${ }^{4}$ integration and scaling of the reflections were performed with the HKL Denzo-Scalepack system of programs. ${ }^{5}$ No absorption corrections were applied.

The structure was solved by direct methods with SHELXS-97. ${ }^{6}$ The model was refined by full-matrix least squares on $\mathrm{F}^{2}$ with SHELXL-97. ${ }^{7}$ All the hydrogen atoms were set isotropic and freely refined. Data collections and experimental details for the complexes are summarized in Table 1. The programs SHELXL-97, ${ }^{7}$ and ORTEP- $3^{8}$ were used within WinGX $\mathrm{X}^{9}$ to prepare materials for publication. Data collections and experimental details for compound $\mathbf{3}$ are summarized in Table 1.

\section{Plant material}

Roots of $R$. echinata were collected in Ressacada, Ibirama, SC, Brazil and identified by A. Reis (Universidade Federal de Santa Catarina) and J. R. Pirani (Universidade de São Paulo). Voucher specimens [A. Reis \& M. Biavatti 2.570 (26/07/98)] were deposited at the Herbário Barbosa Rodrigues (HBR), Itajaí, Santa Catarina, Brazil.

\section{Extraction and isolation of compounds}

The dried and powdered roots (397 g) were extracted with hexane ( $4 \mathrm{~g})$ and $\mathrm{MeOH}(20 \mathrm{~g})$. Successively, the hexane extract was fractionated over silica gel 60 (70-230 mesh) into three fractions: hexane, EtOAc and $\mathrm{MeOH}$. The hexane sub-fraction (576 mg) was chromatographed over silica gel (230-400 mesh) using as eluent $\mathrm{CH}_{2} \mathrm{Cl}_{2}$-EtOAc (9:1 and gradient) to furnish the compounds (in eluting order): fraxinellone (1) (37.1 mg), epoxy-fraxinellone (3) $(76 \mathrm{mg})$, and the fraction named $\mathrm{E}(30 \mathrm{mg})$, that was rechromatographed over silica gel (230-400 mesh) using as eluent $\mathrm{CH}_{2} \mathrm{Cl}_{2}$-EtOAc (99:1 and gradient) to afford fraxinellonone (2) (6 mg).

The methanol extract of the stems $(80 \mathrm{~g})$ was partitioned with dichloromethane (yielding $9 \mathrm{~g}$ ) then chromatographed over silica gel (70-230 mesh) using as eluent hexane-acetone (9:1 and gradient), furnishing 17 sub-fractions (A-P). Subfractions D-G (4.1 g) were grouped and chromatographed over silica gel and hexane-acetone (9:1 and gradient) as eluent, originating sub-fractions A-T. The sub-fraction $\mathrm{T}$ (1.2 g) was purified by preparative TLC using hexanebenzene (1:1), yielding $650 \mathrm{mg}$ of limonexic acid (4).

\section{Identification of the isolated compounds}

The isolated degraded limonoids fraxinellone $e^{10,11,12}(\mathbf{1})$, fraxinellonone $^{10,11,12}(\mathbf{2})$, epoxy-fraxinellone ${ }^{13}(3)$ and limonexic $\operatorname{acid}^{13}(4)$ presented spectral data in agreement with the literature.

epoxy-fraxinellone (3). 5-Furan-3-yl-1a,4a-dimethylhexahydro-1,6-dioxa-cyclopropa[d]inden-7-one, $[\alpha]_{\mathrm{D}}-$ $22.5^{\circ}$ ( $c$ 0.02, $\mathrm{CH}_{2} \mathrm{Cl}_{2}$ ). Colorless needles, mp 80-82 ${ }^{\circ} \mathrm{C}$. Crystallographic data: publication no. CCDC 265853. 
Table 1. Crystal data and structure refinement of compound 3

\begin{tabular}{|c|c|}
\hline Empirical formula & $\mathrm{C}_{14} \mathrm{H}_{16} \mathrm{O}_{4}$ \\
\hline Formula weight & $248.27^{4}$ \\
\hline Temperature & $120(2) \mathrm{K}$ \\
\hline Wavelength & $0.71073 \AA$ \\
\hline Crystal system & Tetragonal \\
\hline Space group & $\mathrm{P}_{1}$ \\
\hline Unit cell dimensions & $\begin{array}{c}a=8.2669(2) \AA \\
c=18.6746(4) \AA\end{array}$ \\
\hline Volume & $1276.25(5) \AA^{3}$ \\
\hline $\mathrm{Z}$ & 4 \\
\hline Density (calculated) & $1.292 \mathrm{Mg} \mathrm{m}^{-3}$ \\
\hline Absorption coefficient & $0.094 \mathrm{~mm}^{-1}$ \\
\hline $\mathrm{F}(000)$ & 528 \\
\hline Crystal size & $0.24 \times 0.18 \times 0.17 \mathrm{~mm}^{3}$ \\
\hline Theta range for data collection & 3.49 to $26.35^{\circ}$ \\
\hline Index ranges & $-10 \leq h \leq 10,-10 \leq k \leq 10,-20 \leq l \leq 23$ \\
\hline Reflections collected & 9664 \\
\hline Independent reflections & $2535[\mathrm{R}(\mathrm{int})=0.0448]$ \\
\hline Completeness to theta $=26.35^{\circ}$ & $99.4 \%$ \\
\hline Absorption correction & None \\
\hline Refinement method & Full-matrix least-squares on $\mathrm{F}^{2}$ \\
\hline Computing ${ }^{a}$ & $\begin{array}{l}\text { COLLECT }^{1}, \text { HKL Denzo and Scalepack } \\
\text { SHELXS- } 97^{3}, \text { SHELXL- } 97^{4}\end{array}$ \\
\hline Data / restraints / parameters & $2535 / 1 / 227$ \\
\hline Goodness-of-fit on $\mathrm{F}^{2}$ & 1.078 \\
\hline Final $R$ indices $[I>2 \geq(I)]$ & $\mathrm{R} 1=0.0328, w \mathrm{R} 2=0.0789$ \\
\hline $\mathrm{R}$ indices (all data) & $\mathrm{R} 1=0.0375, \mathrm{wR} 2=0.0818$ \\
\hline Absolute structure parameter & $0.0(7)$ \\
\hline Largest diff. peak and hole & 0.144 and -0.147 e. $\AA^{-3}$ \\
\hline
\end{tabular}

${ }^{a}$ Data collection, data processing, structure solution and structure refinement respectively.

Atta sexdens bioassay

The toxicity of the compounds to Atta sexdens rubropilosa was determined by ingestion bioassay, according to established protocol described in Bueno et al. (1997). ${ }^{14}$

Each treatment consisted of 50 ants distributed in 5 Petri dishes. The leaf-cutting ants were isolated from their nest and fed with an artificial diet. The ants from the treatment received a diet added with epoxy-fraxinellone or limonexic acid, at a concentration of $200 \mu \mathrm{g}$. The ants from the control treatment were fed with a diet without this compound.

During 25 days, the number of dead ants for each Petri dish was counted and a new portion of artificial diet given. It was estimated the survival curve of leaf-cutting ants of each treatment and calculated the median longevity. The test used for the statistic analyze of data was the Log rank-test $(\alpha=0.05)$.

\section{Results and Discussion}

The isolated degraded limonoids $\mathbf{1 - 3}$ were respectively identified as fraxinellone (1), fraxinellonone (2), epoxyfraxinellone (3) and limonexic acid (4) by comparison with the spectral data described in the literature. ${ }^{10-13}$

Epoxy-fraxinellone has a quaternary epoxy group attached to $\mathrm{C} 8-\mathrm{C} 14$, instead of the double bond as in fraxinellone. The spectroscopic data published ${ }^{13}$ could not furnish clear evidence of the spatial configuration of this moiety. In an attempt to confirm the epoxy group position, nOe difference experiments were performed, but the defining signals were superimposed (in $d$-chloroform and benzene- $d_{6}$ ), frustrating clear conclusions. In order to solve these indistinguishable findings, an X-ray analysis (Figure 1) was performed to confirm the epoxy group position.

Single crystal of epoxy-fraxinellone was produced by recrystallization followed by a crystal-growing process. The recrystallization involved dissolution of the material in proper amount of ethyl acetate-acetone followed by drops of water. Suitable crystals were selected and analysed by single crystal X-ray diffraction which established undoubtedly the structure of the compound 3 . Figure 1 shows an Ortep ${ }^{8}$ type view of $\mathbf{3}$ showing the thermal ellipsoids and atoms labels. This study shows that the molecular conformation of $\mathbf{3}$ is fixed by the presence of three main intramolecular interactions (Table 2). The analyses of the crystal packing showed the presence of others three intermolecular interactions in $\mathbf{3}$ (Table 3 ). These interactions give rise to the formation of infinite chains along the $c$ axis (Figure 2). All geometrical details of the intermolecular contacts were interpreted as 


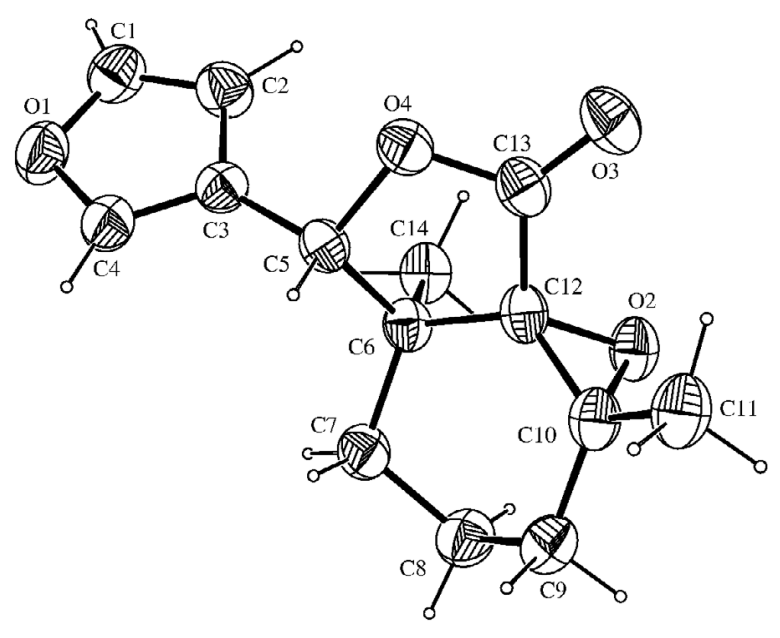

Figure 1. ORTEP-3 view of the asymmetric unit of 3 , showing the atoms labelling and the $50 \%$ probability ellipsoids.

intermolecular interactions on geometrical grounds, ${ }^{15}$ and the Table 2 show their selected geometrical parameters.

The structures of compounds $\mathbf{1}$ and $\mathbf{2}$ were elucidated on the basis of ${ }^{1} \mathrm{H}$ NMR and EIMS spectra, and were in agreement with published data. ${ }^{10-12}$ The EI-mass spectra of both compounds shown to be formed mainly from the molecular ion by the consecutive exclusion of furan-3aldehyde, $\mathrm{CH} 3, \mathrm{HCHO}$ and $\mathrm{CO}$ fragments.

As previously reported, crude extracts of leaves and stems as well as fractions of $R$. echinata showed good inhibitory activity on L. gongylophorus growth, the fungus cultured by the leaf-cutting ant Atta sexdens rubropilosa. ${ }^{16}$

Epoxy-fraxinellone showed not be toxic to the leafcutting ants, although limonexic acid displayed a significant reduction on lifetime (11 days) of leaf cutting ants, when compared with the control group (22 days) (Figure 3).

Limonexic acid was also isolated from Dictamnus angustifolius $^{17}$ a traditional plant used in China and from Tetradium trichotomum ${ }^{18}$ root barks, and together with isolimonexic acid are the main constituents of the fruit of

Table 2. Intramolecular and intermolecular interactions geometry $\left(\AA,{ }^{\circ}\right)$ of compound $\mathbf{3}$

\begin{tabular}{|c|c|c|c|c|}
\hline D-H...A & D-H & D....A & H......A & D-H......A \\
\hline \multicolumn{5}{|c|}{ Intramolecular interactions } \\
\hline C8-H8A...O2 & $1.03(2)$ & $2.909(2)$ & $2.66(2)$ & $93(1)$ \\
\hline C14-H14B...O2 & $0.99(2)$ & $2.980(2)$ & $2.74(2)$ & $94(1)$ \\
\hline C11-H11B...O3 & $0.98(2)$ & $3.246(2)$ & $2.50(2)$ & 131(1) \\
\hline \multicolumn{5}{|c|}{ Intermolecular interactions } \\
\hline $\mathrm{C} 4-\mathrm{H} 4 \ldots \mathrm{O}^{i}$ & $0.93(2)$ & $3.140(2)$ & $2.35(2)$ & $142(1)$ \\
\hline $\mathrm{C} 9-\mathrm{H} 9 \mathrm{a} \ldots \mathrm{O} 2^{i}$ & $1.00(2)$ & $3.309(2)$ & $2.54(2)$ & $133(1)$ \\
\hline $\mathrm{C} 5-\mathrm{H} 5 \ldots \mathrm{O} 3^{i}$ & $1.03(2)$ & $3.546(2)$ & $2.70(2)$ & 139(1) \\
\hline
\end{tabular}

Symmetry codes: $(i)-\mathrm{y}+1,+\mathrm{x},+\mathrm{z}+1 / 4$.

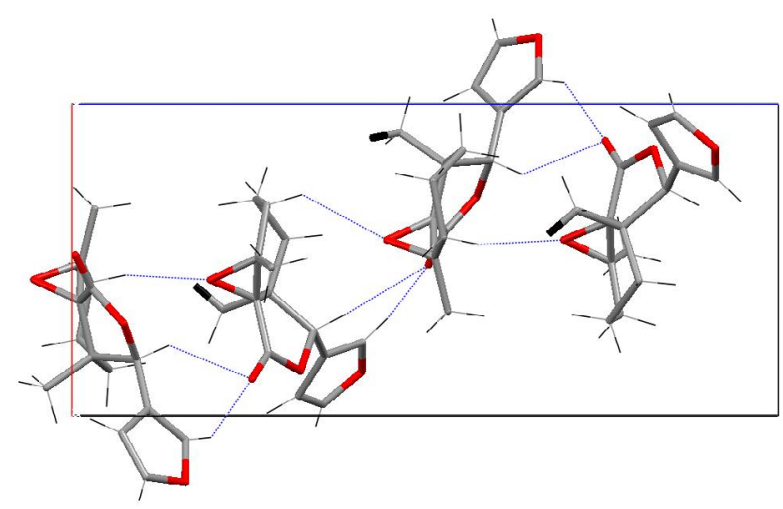

Figure 2. Intermolecular interactions in $\mathbf{3}$ that form an infinite chain along the $c$ axis.

Citrus nippokoreana.$^{19}$ Despite being known since $1948,{ }^{20}$ no significant reference of its bioactivity was found.

Just a dozen degraded limonoids have been published, mainly from Rutaceae and Meliaceae plants. As the parent limonoids, some of them have been tested for biological activities including antifeeding and growth regulating activities against insects, and some relationship between the structures and biological activity has been studied. ${ }^{11}$
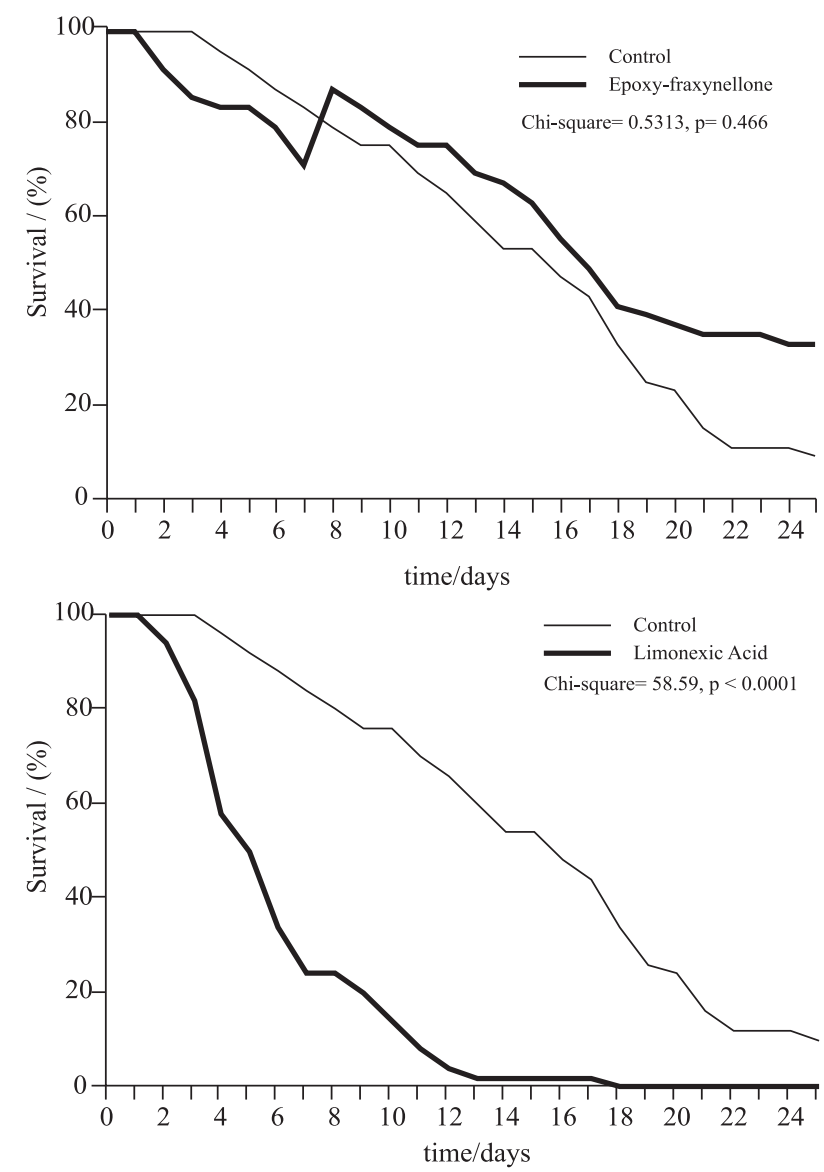

Figure 3. Survival curve of leaf-cutting ants for treatment and control, calculated the median longevity. Statistic analyze of data: log rank-test $(\mathrm{a}=0.05)$. 
In roots they were also found in Melia azedarach ${ }^{21}$ and Dictamnus dasycarpus. ${ }^{12}$

Ichthyotoxic and insect antifeedant activities have been described for fraxinellone and fraxinellonone against Oryzias latipes and Spodoptera littoralis respectively. ${ }^{10}$ Antifertility, antiplatelet aggregation and vasorelaxant activities are also described for fraxinellone, that also reduced the growth rate and food consumption of both adults and larvae of Tribolium castaneum at concentration of $10 \mathrm{ppm}$ and above in a concentration dependent manner, but was less active than commercial feeding deterrents. ${ }^{12}$

\section{Supplementary Information}

Supplementary Crystallographic data have been deposited with the Cambridge Crystallographic Data Centre as supplementary publication no. CCDC 265853. Copies of available material can be obtained, free of charge on application to the Director, CCDC, 12 Union Road, Cambridge CH2 1EZ, UK (fax: +44-1223-336-033 or e-mail: deposit@ccdc.cam.ac.uk or http://www. ccdc.cam.ac.uk).

\section{Acknowledgements}

We wish to thank Prof. A. Reis for collecting and identifying, Prof. J. R. Pirani for identifying the plant material and $\mathrm{CNPq}$ for financial support.

\section{References}

1. Kaastra, R.C.; Flora Neotropica, monograph n. 33, 1982.

2. Biavatti, M.W.; Vieira, P. C.; Silva, M. F. G. F. da; Fernandes, J. B.; Albuquerque, S.; Magalhães, C. M. I.; Pagnocca, F. C.; Phytomedicine 2001, 8, 121.

3. Silva, A.; Bacci Jr., M.; Siqueira, C. G.; Bueno, O. C.; Pagnocca, F. C.; Hebling, M. J. A.; J. Insect Physiol. 2003, 49, 307.

4. Enraf-Nonius COLLECT.; Nonius BV, Delft, The Netherlands, 1997-2000.
5. Otwinowski, Z.; Minor, W. In Methods in Enzymology; Carter Jr., C.W.; Sweet, R.M., eds.; Academic Press: New York, 1997, vol. 276, pp. 307-326.

6. Sheldrick, G.M.; SHELXS-97, Program for Crystal Structure Resolution; Univ. of Göttingen: Göttingen, Germany, 1997.

7. Sheldrick, G.M.; SHELXL-97, Program for Crystal Structures Analysis; Univ. of Göttingen: Göttingen, Germany, 1997.

8. Farrugia, L. J.; ORTEP-3 for Windows; J. Appl. Crystallogr. 1997, 30, 565 .

9. Farrugia, L. J.; Win, G. X.; J. Appl. Crystallogr. 1999, 32, 837.

10. Nakatani, M.; Huang, R.C.; Okamura, H.; Iwagawa, T.; Tadera, K.; Phytochemistry 1998, 49, 1773.

11. Okamura, H.; Yamauchi, K.; Miyawaki, K.; Iwagawa, T.; Nakatani, M.; Tetrahedron Lett. 1997, 38, 263.

12. Liu, Z.L.; Xu, Y.J.; Wu, J.; Goh, S.H.; Ho, S.H.; J. Agric. Food Chem. 2002, 50, 1447.

13. Biavatti, M.W.; Vieira, P. C.; Silva, M. F. G. F. da; Fernandes, J. B.; Albuquerque, S.; Z. Naturforsch., C: J. Biosci. 2001, 56, 570 .

14. Bueno, O. C.; Morini, M. S. C.; Pagnocca, F. C.; Hebling, M. J. A.; Silva, O. A.; An. Soc. Entomol. Brasil 1997, 26, 107.

15. Ellena, J.; Goeta, A. E.; Howard, J. A. K.; Punte, G.; J. Phys. Chem. 2001, A105, 8696.

16. Biavatti, M.W.; Vieira, P. C.; da Silva, M. F. G. F.; Fernandes, J.B.; Victor, S. R.; Pagnocca, F. C.; Albuquerque, S.; Caracelli, I.; Zukerman-Schpector, J.; J. Braz. Chem. Soc. 2002, 13, 66.

17. Wu, T-S.; Li, C-Y.; Leu, Y-L.; Hu, C-Q.; Phytochemistry 1999, 50, 509.

18. Quader, A.; But, P.P.; Gray, A.I.; Hartley, T.G.; Hu, Y.; Waterman, P.G.; Biochem. Syst. Ecol. 1990, 18251.

19. Connolly, J.D.; Hill, R.A.; Nat. Prod. Rep. 2001, 5, 560.

20. Kondo, Y.; Suzuki, H.; Nozoe, S.; Yakugaku Zasshi 1985, 105, 742

21. D’Ambrosio, M.; Guerriero, A.; Phytochemistry 2002, 60, 419.

Received: May 18, 2005

Published on the web: September 22, 2005

FAPESP helped in meeting the publication costs of this article. 